
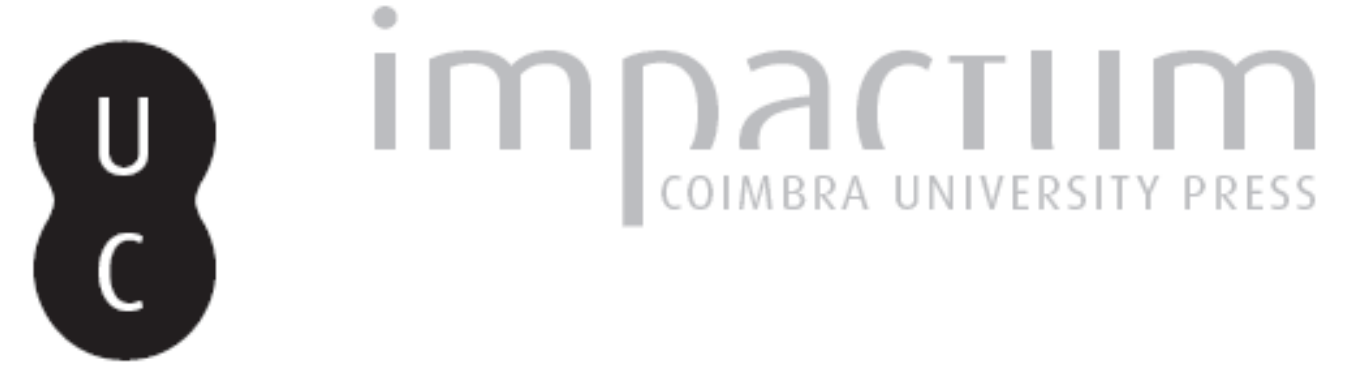

“Estas cousas Señora filha vos peço e encomemdo": a imagem de consorte na
família real portuguesa a partir das instruções de D. Manuel para D. Beatriz (1504-
1538 )

Autor(es): $\quad$ Silva, João Eusébio

Publicado por: Centro de História da Sociedade e da Cultura

URL

persistente:

URI:http://hdl.handle.net/10316.2/39429

DOI:

DOI:http://dx.doi.org/10.14195/1645-2259_12_8

Accessed : $\quad$ 26-Apr-2023 15:41:11

A navegação consulta e descarregamento dos títulos inseridos nas Bibliotecas Digitais UC Digitalis, UC Pombalina e UC Impactum, pressupõem a aceitação plena e sem reservas dos Termos e Condições de Uso destas Bibliotecas Digitais, disponíveis em https://digitalis.uc.pt/pt-pt/termos.

Conforme exposto nos referidos Termos e Condições de Uso, o descarregamento de títulos de acesso restrito requer uma licença válida de autorização devendo o utilizador aceder ao(s) documento(s) a partir de um endereço de IP da instituição detentora da supramencionada licença.

Ao utilizador é apenas permitido o descarregamento para uso pessoal, pelo que o emprego do(s) título(s) descarregado(s) para outro fim, designadamente comercial, carece de autorização do respetivo autor ou editor da obra.

Na medida em que todas as obras da UC Digitalis se encontram protegidas pelo Código do Direito de Autor e Direitos Conexos e demais legislação aplicável, toda a cópia, parcial ou total, deste documento, nos casos em que é legalmente admitida, deverá conter ou fazer-se acompanhar por este aviso. 
evista de História da Sociedade e da Cultura

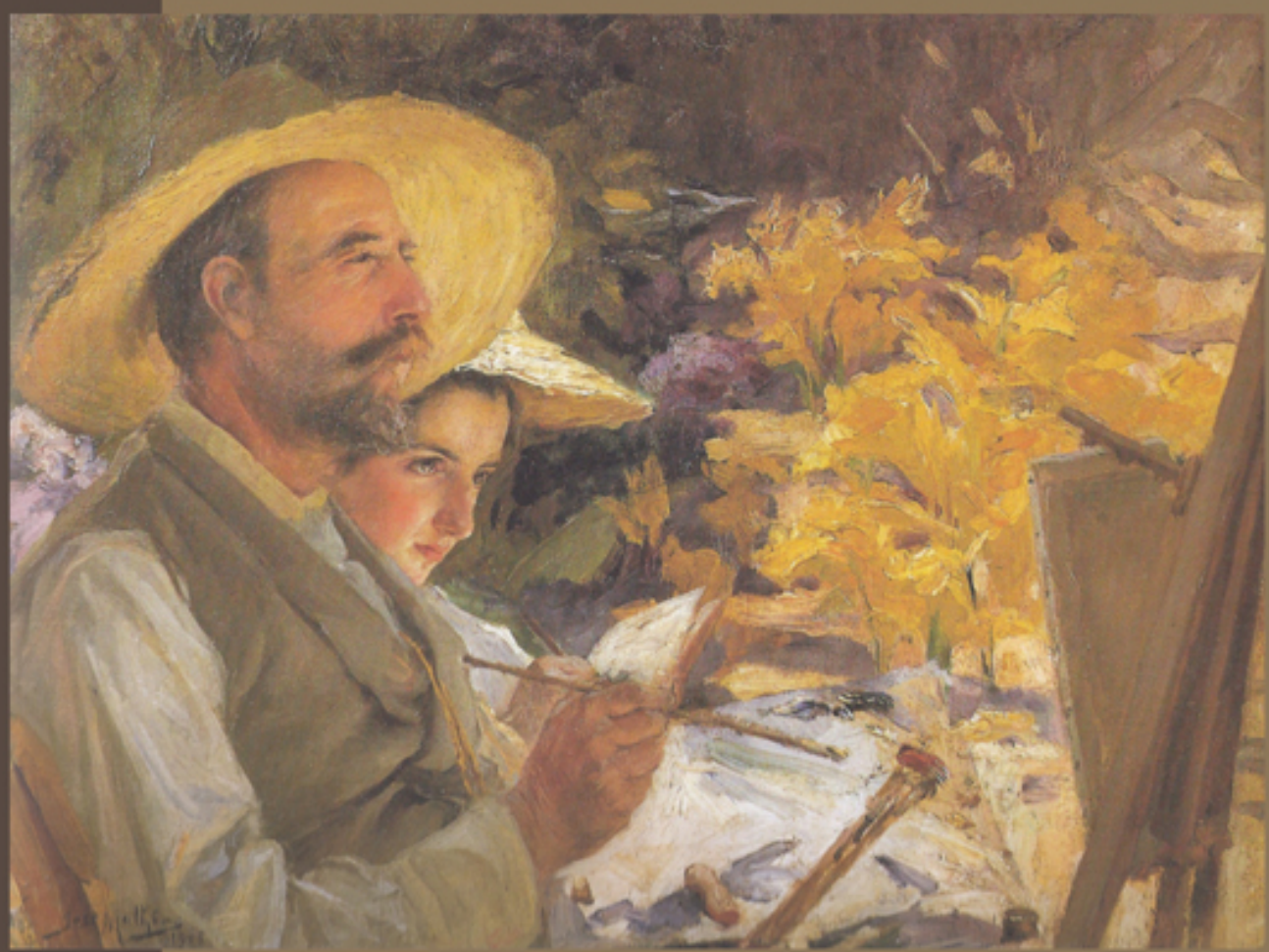

Centro de História da Sociedade e da Cultura Universidade de Coimbra 


\title{
"Estas cousas Señora filha vos peço e encomemdo": A imagem de consorte na família real portuguesa a partir das instruções de D. Manuel para D. Beatriz (1504-1538)
}

\author{
João Eusébio Silva \\ Centro de História de Além-Mar - Faculdade de Ciências Sociais e Humanas \\ da Universidade Nova de Lisboa \\ joaor.eusebio@gmail.com \\ Texto recebido em /Text submitted on: 01/03/2012 \\ Texto aprovado em / Text approved on: 09/04/2012
}

\section{Resumo/Abstract:}

Em Agosto de 1521 a armada que transportava D. Beatriz de Portugal, duquesa de Saboia, zarpava do Tejo rumo a Nice. A bordo seguia a filha de D. Manuel de Portugal com um numeroso e representativo séquito e dote, exemplo do que a coroa portuguesa tinha de melhor em luxo e aparato. Este era de resto um dos mecanismos utilizados por D. Manuel I na afirmação do seu poder: a utilização dos símbolos e das imagens em torno da família real como forma de afirmação política e social da coroa. Seguindo esta linha de pensamento havia o monarca Português escrito as suas Instrucções para a sua filha que agora casava, documento ímpar na análise do modelo de consorte régia no século XVI, para lá daquele que nos é dado pela cronística e pelos tratadístas. A partir desta preciosa fonte escrita pelo rei de Portugal do que se esperava de uma princesa, juntamente com apontamentos da vida desta infanta de Portugal e da sua mãe, D. Maria de Aragão, rainha de Portugal, pode-se reconstruir as linhas que ditavam a conduta de vida destas mulheres tão próximas dos centros de poder, mas que surgem por diversas vezes como meras "sombras" na história.

On August 1521, the fleet transporting D. Beatriz of Portugal, duchess of Savoy, set sail from the Tagus River to Nice. On board was the daughter of D.Manuel of Portugal with an enormous entourage and an impressive dowry, showcasing the luxury and the grandeur of the Portuguese crown. This was after all one of the ways D. Manuel used as a confirmation of his power: the use of the symbols and images surrounding the royal family as a form of political and social affirmation of the crown. Following this line of thought, the Portuguese king had written his Instrucções for his marrying daughter, an unique document when analyzing the model of the royal consort in the 16th century, beyond what is given to us by the chroniclers and the authors of moral treaties. From this valuable written source by the king of Portugal, of what was expected of a princess, together with real life events of this Portuguese Infanta and of her mother, D. Maria of Aragon Queen of Portugal, we can reconstruct the guide lines to the life conduct of these women so close to the power centres but that so often appear to be mere "shadows" in History.

Palavras chave/Keywords:

Século XVI; Cultura política; Casa real; Rainha de Portugal; Beatriz; Duquesa de Saboia.

16th Century; Political Culture; Royal Household; Queen of Portugal; Beatriz; Duchess of Savoy. 


\section{Introdução: D. Beatriz, uma infanta de Portugal, duquesa de Saboia}

No último dia do ano de 1504 nos paços da Alcáçova nascia D. Beatriz de Portugal, terceira descendente dos reis de Portugal ${ }^{1}$. As crónicas não fornecem muito no que diz respeito ao seu nascimento, tal como ao resto da sua existência para além do seu casamento. Damião de Góis afirma porém que, visto se encontrar D. Maria no término da sua terceira gravidez, vindo a dar à luz D. Beatriz, não lhe foi comunicada a morte da sua mãe, Isabel a Católica, rainha de Castela, de modo a não afligir e prejudicar a gestação².

Como terá assim sido a infância e a educação desta filha de D. Manuel de Portugal? Poucas referências se encontram nas fontes sobre este ponto. Se no caso de D. João, herdeiro do trono, encontramos o nome de alguns mestres e das suas práticas enquanto criança e aluno, poucas ou nenhumas referências encontramos no que diz respeito a D. Beatriz. Uma das poucas certezas sobre a educação desta infanta reside no facto de, após a morte da sua mãe em 1517, D. Manuel ter nomeado Elvira Mendonça, antiga camareira-mor da rainha, como aia das infantas, "tendo em conta as virtudes necessárias e a sabedoria para lhes ensinar o que cumpre ao seu estado"'. O conde de Sabugosa apresenta uma visão um tanto ou quanto romanceada da juventude desta infanta, mas que poderá de certo modo ter correspondido à verdade. Segundo este, a jovem de 13 anos, educada nos costumes virtuosos da sua mãe, mas possuindo uma certa altivez que lhe seria inata, terá visto com satisfação a chegada dos embaixadores de Saboia para negociarem o seu casamento ${ }^{4}$.

Em 1516 o ducado de Saboia havia proposto este matrimónio, algo que não foi aceite na altura, talvez por oposição de D. Maria que deixava bem claro no seu testamento a ideia de que era indesejável o casamento de

1 GÓIS, Damião de-Chrónica do felicissimo rei dom. Emanuel, Lisboa: por Francisco Correa, 1566, Pt. I, Cap. LXXXII, fl. 80.

2 GÓIS, Damião de - Chrónica do felicissimo..., cit., Pt. I, Cap. LXXXII, fl. 80.

3 Instituto Arquivos Nacionais/Torre do Tombo (Lisboa), Chancelaria D. Manuel, liv. 25, fl. 172 .

4 SABUGOSA, Conde de - Donas de tempos idos, Lisboa: Livraria Ferreira, 1912, p. 119. 
uma das suas filhas com algum príncipe que não fosse rei ou filho de rei ${ }^{5}$. Assim, em 1516, D. Manuel alegaria a pouca idade da infanta para a realização deste casamento, existindo mesmo indícios de alguma oposição por parte desta a este projecto ${ }^{6}$. Ao falar do "mercado das princesas", Bartolomé Benassar afirma que a Saboia, assim como a Baviera, o Palatinado e os territórios italianos serviam para os segundos filhos, nunca para os primogénitos ${ }^{7}$, o mesmo se poderá dizer das filhas.

Como foi notado por João Paulo Oliveira e Costa, a propósito do casamento da filha mais nova do monarca português com o duque de Saboia, casamento considerado de pouco prestígio por alguns, na segunda década do século XVI poucas eram as opções dinásticas de interesse geopolítico para a coroa Portuguesa ${ }^{8}$. A escolha residia entre Carlos V ou Carlos III de Saboia, pelo que, segundo a ordem de primogenitura e de interesses políticos, era lógico que o casamento com Saboia fosse consumado com a filha mais nova do rei de Portugal'.

Não cabendo aqui a descrição completa de como decorreu a sua vida, com as suas glórias e misérias, importa referir que este matrimónio terá representando o último acto apoteótico do reinado manuelino. Após as suas reticências iniciais face ao processo, tendo mandado Silvestre Nunes a Saboia de forma a inquirir a situação do ducado, D. Manuel acedia finalmente à proposta do duque Carlos III de Saboia ${ }^{10}$. As cerimónias que

5 (As) Gavetas da Torre do Tombo, Lisboa: Centro de Estudos Históricos Ultramarinos, 1960-1977, vol. VI, Gav. XVI, 2-1, p. 108-109.

6 BUESCU, Ana Isabel - D. João III. 1502-1557, Lisboa: Temas e Debates, 2008, p. 108-109.

7 BENASSAR, Bartolomé - A Cama, o Poder e a Morte. Rainhas e Princesas da Europa do Renascimento ao Ilumininismo. Lisboa: Temas e Debates/Círculo de Leitores, 2009, p. 43.

8 Cf. COSTA, João Paulo Oliveira e - D. Manuel I. 1469-1521 Um príncipe do Renascimento, Lisboa: Temas e Debates, 2007, p. 366.

9 COSTA, João Paulo Oliveira e-D. Manuel I, cit., p. 365. Já Sousa Viterbo, ao referir o motivo que terá levado Carlos III a procurar um casamento em Portugal, compara o duque de Saboia a um nobre arruinado que procurava por meio de um casamento opulento redourar o seu brasão (VITERBO, Joaquim de Santa Rosa de - O dote de D. Beatriz de Portugal duqueza de Saboya. in Archivo Histórico Portuguez, Vol. VI, Lisboa: 1908, p. 4-24, p. 6).

${ }^{10}$ GÓIS, Damião de - Chrónica do felicissimo..., cit., Pt. IV, Cap. LXX, fl. 86v-87. 
então decorreram em Lisboa, descritas por Garcia de Resende ${ }^{11}$, consumavam o casamento da segunda filha do monarca português ao mesmo tempo que mostravam toda a riqueza da sua coroa. A armada que levava a nova duquesa de Saboia e o seu séquito seria encabeçada pela nau Santa Catarina do Monte Sinai, paramentada de dourado branco e carmesim ${ }^{12}$, de forma a representar a corte portuguesa e a sua "sua muyta grandeza e poder"13.

Do seu casamento, do qual terá resultado uma relação se não de amor pelo menos de uma profunda cumplicidade, nasceriam 9 filhos, sobrevivendo apenas um que herdaria os títulos dos seus progenitores com o nome de Emanuel Filiberto, tendo sido de resto esta infanta de Portugal a introduzir o nome Emanuel na casa de Saboia, em honra do seu pai, o qual perduraria até aos dias de hoje.

Seria a esta filha que D. Manuel endereçaria as suas Instruções ${ }^{14}$, respondendo assim a um pedido desta e dizendo-lhe que o fazia pelo amor que lhe tinha e pelo "desejo de serdes a maior acabada e prefeyta princesa que nunca foy"15. Através delas podem-se descortinar as práticas e os conceitos em torno do que representava ser consorte de um soberano na corte

${ }^{11}$ Ao descrever por exemplo um dos serões oferecidos por D. Manuel durante os festejos, Garcia de Resende diz: "Em ua mui grande armada toda mui rica tapeçaria d'ouro, e muito bem alcatifada, dorsel, cadeiras e almofadas de mui rico brocado, se começou um grande serão, em que el rei nosso senhor dançou com a senhora infante duquesa sua filha, e a rainha nossa senhora com a infante dona Isabel, o príncipe nosso senhor e o senhor infante dom Luís com damas tomaram. E assi dançaram todos os galantes que iam a Saboia, e muitos outros senhores e galantes, que durou muito. E danças acabadas se começou ua muito boa, e muito bem feita comédia de muitas figuras muito bem ataviadas, e muito naturais, feita e representada ao casamento e partida da senhora infante, cousa muito bem ordenada e bem a propósito, e com ela acabada se acabou o serão" (RESENDE, Garcia de - Crónica de D. João II e Miscelanêa, Lisboa: Imprensa Nacional-Casa da Moeda, 1991, p. 322).

${ }_{12}$ CORREIA, Gaspar - Crónicas de D. Manuel e de D. João III (até 1533), COSTA, José Pereira da (Intr. Leitura e notas), Lisboa: Academia das Ciências, 1992, p. 145.

${ }^{13}$ CORREIA Gaspar - Crónicas ..., cit., p. 144.

${ }^{14}$ Estas encontram-se transcritas em CARVALHO, José Adriano de Freitas - Pais e Nobres. Vol. I - Cartas de Instrução para Educação de Jovens Nobres. Séculos XVI-XVIII, Vol. I, Porto: Centro Inter-Universitário de História da Espiritualidade, 2009. Publicadas também por Aníbal Fernandes Tomaz, Cartas bibliographicas, 2a série, Coimbra, 1877, p. 15-23, que, por sua vez, as copiou da rara edição oferecida pelo Visconde de Alte a partir da reprodução fotográfica de um ms. do A.G. R. Itália, Turim, em 1856, onde se encontrava: Istruzione del Re di Portugallo Emanuele, a Beatrice Duchezza di Savoya, sua figlia, in lingua portoghese, e dal medesimo sotoscritta.

${ }^{15}$ Cit. por CARVALHO, José Adriano de Freitas - Pais e Nobres..., cit., Vol. I, p. 261. 
portuguesa quinhentista, constituíndo assim este documento um testemunho imprescindível na compreensão do que a cultura política e social entendia como o papel de uma mulher no seio da corte, como consorte de um monarca.

\section{2. vosos boos conselhos e lembranças lhe façam muyto proveyto ${ }^{16}$ : O papel de perfeita esposa e principal conselheira}

Ernst Kantorowicz afirmou que o corpo político não tinha nem personalidade nem sexo ${ }^{17}$, ignorando no entanto o papel das consortes régias e o peso das relações familiares como parte do sistema monárquico. Desenvolvido nos espaços privados, através de mecanismos silenciosos a nível de registo histórico, mas sem dúvida reais, baseados nas dinâmicas resultantes dos afectos e relações conjugais, as mulheres da família real decerto teriam alguma espécie de influência numa sociedade onde ocupavam um lugar tão central, sendo os afectos entre marido e mulher, segundo alguns autores, mais fortes que entre pais e filhos ${ }^{18}$.

Encontramos assim no papel da consorte do monarca aquilo a que se pode chamar o poder do privado, uma forma de influência e poder baseada não numa titulação institucional, mas sim na proximidade ao centro de poder. Poder-se-ia dizer que o papel da rainha no conjunto das relações de poder político assentava em duas bases. Por um lado o representativo, baseado na posse de bens e na distribuição de mercês, beneficência, e no patrocínio aos que a ela recorriam, como mãe e esposa, sendo que neste último papel se podia encontrar a sua segunda base de influência e poder, fruto da sua vivência no mundo privado da família real, da qual fazia parte ${ }^{19}$.

${ }^{16}$ Cit. por CARVALHO, José Adriano de Freitas - Pais e Nobres..., cit., Vol. I, p. 262.

${ }^{17}$ KANTOROWICZ, Ernst - The King's Two Bodies: A Study in Medieval political Theology, $7^{\circ}$ ed., Princeton: Princeton Univ. Press, 1997, p. 80.

${ }^{18}$ HESPANHA, António Manuel - Carne de uma só carne: para uma compreensão dos fundamentos histórico-antropológicos da família na época moderna, in Análise Social, vol. XXVIII (123-124), 1993 (4. $\left.{ }^{\circ}-5^{\circ}\right)$, p. 951-973, p. 956.

${ }^{19}$ EARENFIGHT, Theresa - Without the Persona of the Prince: Kings, Queens and the Idea of Monarchy in Late Medieval Europe, in Gender \& History, vol. 19, No. 1, 2007, p. 1-21, p. 9-10. 
O conceito de público e privado estava presente na vida política do início da Época Moderna ${ }^{20}$.

Nas Instruções que D. Manuel deu à sua filha pode-se assim ler: “(...) vos roguo que sempre tenhaes muyto cuidado em amardes e comtemtardes a vosso marido e de nunca fazerdes cousa de seu descontemtamento, e em tal maneyra que amtre vós e ele se usa aver desvayro algum, e o que vos parecer que hé seu louvor e que elle deve fazer, sempre lho leenbray, e em tal modo que vosos boos conselhos e lembranças lhe façam muyto proveyto e elle conheça que lhas fazees com o muito amor que lhe temdes, fazemdo sempre com aquele acatamento que hé rezam e que as molheres a seus maridos devem de ter" 21 .

O rei de Portugal, na sua qualidade de pai, indicava à sua filha o modo como devia apoiar o seu marido com bons conselhos, tendo como objectivo a sua maior honra e glória. Anos mais tarde o Libro Primero del espejo de la Princesa Christiana (c. 1543) é disso exemplo, ao pretender, mais do que formar e educar, orientar e apoiar a princesa, apresentando as treze condições que deveria possuir a princesa perfeita, sendo a primeira o papel de conselheira do seu marido ${ }^{22}$.

Encontramos nas Instruções uma indicação clara e objectiva de um dos "conselhos" de D. Manuel, sendo que D. Beatriz devia lembrar o seu marido quando "ho caso oferecer, que queyra procurar quanto a elle seja possível a paz y concórdia dantre o emperador e ElRey de França, porquanto serviço niso se fará a Nosso Señor e a ele e a vós tamto louvor"23. Este terá sido efectivamente um dos "conselhos" que D. Beatriz transmitiu a Carlos III. Damião de Góis, por exemplo, não se coíbe de afirmar que o resultado deste conselho terá sido catastrófico para o duque de Saboia ${ }^{24}$.

${ }^{20}$ CARDIM, Pedro - Os Espaços da Vida Privada. A Corte Régia e o Alargamento da Esfera Privada. in Mattoso, José (dir.), História da Vida Privada em Portugal. A Idade Moderna, Vol II, Lisboa: Temas e Debates/Circulo de Leitores, 2011, p. 160-201, p. 194.

${ }^{21}$ Cit. por CARVALHO, José Adriano de Freitas - Pais e Nobres ..., cit., Vol. I, p. 262.

${ }^{22}$ BUESCU, Ana Isabel - Imagens do príncipe. Discurso normativo e representação (1525-1549), Lisboa, Cosmos, 1996, p. 217.

${ }^{23}$ Cit. por CARVALHO, José Adriano de Freitas - Pais e Nobres..., cit., Vol. I, p. 264.

24 "Por satisfazer ao apetite da Duquesa Infante sua molher fauorecia contra elle [Francisco I] o Emperador dom Carlos quinto do nome (...), per cuja causa socederam todalas perdas, damnos, \& desauenturas, que o Duque Charles feu marido passou ate que morreo" (GÓIS, Damião de - Chrónica do felicissimo ..., cit., Pt. IV, Cap. LXX, fl. 89). 
Também segundo Pierre de Bourdeille, cronista francês, "ceste belle soeur [de Carlos V] rendoit pareille amour à son beau frere: de telle sorte qu'elle fist perdre l'estat à son mary, car elle ne cessa jamais qu'elle ne le brouillast au party de l'empereur"25. Já segundo Gaudenzio Clareta, um dos poucos biógrafos desta infanta de Portugal, D. Beatriz nunca entrou em desacordo com Carlos III, chamado o Bom, sendo que com a sua sabedoria política aconselhou e melhorou o frágil ducado do seu marido, assumindo o governo do ducado em conjunto com este desde o primeiro ano de casamento ${ }^{26}$.

Concordando ou discordando, parece no entanto certo afirmar que D. Beatriz de Portugal desempenhou a sua função de conselheira do seu marido como lhe era prescrito pelo seu pai em 1521. Menos visível, mas não menos verdadeira, terá sido também a influência da sua mãe D. Maria, descrita como "muy santa em seu vyver"27, junto de D. Manuel. Esta infanta de Castela e Aragão, tornada rainha de Portugal terá tido um relativo peso e influência política na corte manuelina. Alexandra Pelúcia, por exemplo, aponta-a como uma das maiores defensoras e apoiantes políticas das ideias imperialistas de Afonso de Albuquerque, protestando veementemente aquando da troca deste por Lopo Soares de Albergaria, levando D. Manuel a reflectir e a voltar atrás na sua decisão, sem no entanto o conseguir ${ }^{28}$. Exemplo dessa influência pode também ser visto em Janeiro de 1504 quando por carta D. Manuel atribui um perdão aos moradores de Azamor que haviam saqueado e morto alguns portugueses pertencentes a uma armada enviada pelo rei. Acção digna de castigo exemplar vê-se assim relevada pelo monarca, segundo as suas palavras, a pedido de "quem de nós he muito chegada, e mais estimada a Rainha nossa consorte" a quem os moradores de Azamor haviam dirigido uma súplica confessando a sua culpa. Documento de chancelaria, adquire grande importância neste contexto,

${ }^{25}$ BOURDEILLES, Pierre de - Oeuvres complètes de Pierre de Bourdeilles, Vol. II, Paris: P. Jannet Libraire, 1858, p. 150-151.

${ }^{26}$ CLARETA, Gaudenzio - Notizie storiche intorno alla vita ed ai tempi di Beatrice di Portogallo con documenti, Turim: Tip. Eredi Botta, 1863, p. 54.

${ }^{27}$ CORREIA, Gaspar-Crónicas ..., cit., p. 125.

${ }^{28}$ Cf. PELÚCIA, Alexandra - A Baronia do Alvito e a expansão manuelina no Oriente ou a reacção organizada à política imperialista, in COSTA, João Paulo Oliveira e RODRIGUES, Vítor Luís Gaspar (ed.) - A Alta Nobreza e a Fundação do Estado da Índia. Colóquio Internacional. Actas. Lisboa: UNL/CHAM, IICT/CEHCA, 2004, p. 279-302, p. 290-292. 
visto ser o próprio monarca a reconhecer, a influência que a sua mulher detinha nas suas decisões, reconhecendo que concede este perdão "por seu respeito" 29.

D. Manuel revelava assim nas suas Instruções uma prática corrente no que diz respeito ao poder das consortes régias em função da sua presença no mundo doméstico e privado do monarca e da dialéctica entre cônjuges ${ }^{30}$. A mulher como conselheira do seu cônjuge, nem sempre reconhecida pela historiografia que tende a ignorar a figura das consortes régias nos mecanismos políticos da época moderna, silenciada pela cronística e debatida pelos moralistas ${ }^{31}$, que defendendo ou não a inferioridade da mulher face ao homem no campo social, político e intelectual ${ }^{32}$, não deixavam de apontar o papel de conselheira do seu esposo, para as jovens que se casavam ${ }^{33}$.

\section{3. receber de vós muita homrra e gasalhado ${ }^{34}$ : A distribuição, o patrocínio e o bom governo da casa}

A cultura popular do início da Idade Moderna, expressa nos cancioneiros e romances, apresentava a imagem de uma sociedade misógina, ridicularizando a mulher e a sua inferioridade dentro da família ${ }^{35}$. Gil Vicente por exemplo, acerca do governo da casa, poria o escudeiro na Farsa de Inês Pereira a dizer: "Vós não haveis/ de mandar/ em casa, num só cabelo;/ se eu disser: isto é novelo! -,/ havei-lo de confirmar" ${ }^{36}$.

${ }^{29}$ SOUSA, João de - Documentos arábicos: para a história portugueza, Lisboa: Academia Real das Sciências de Lisboa, 1790, p. 8.

${ }^{30}$ EARENFIGHT, Theresa - Without the Persona of The Prince..., cit., p. 12.

${ }^{31}$ BUESCU, Ana Isabel - Imagens do príncipe ..., cit., p. 218.

${ }^{32}$ BUESCU, Ana Isabel - Imagens do príncipe ..., cit., p. 215-216.

${ }^{33}$ Francisco de Monçon coloca a capacidade de dar sábios conselhos ao rei como a primeira das qualidades que uma rainha deve ter. Cf. BUESCU, Ana Isabel - Imagens do príncipe ..., cit., p. 217.

${ }^{34}$ Cit. por CARVALHO, José Adriano de Freitas - Pais e Nobres..., cit., Vol. I, p. 264.

${ }^{35}$ Cf. LÓPEZ-CORDÓN Cortezo, María Victoria - Familia, sexo y género en la España moderna, in Studia historica. Historia moderna, No 18, 1998, p. 105-134, p. 123.

${ }^{36}$ VICENTE, Gil - Compilaçam de todalas obras, BUESCU, Maria Leonor Carvalhão (ed.), Vol. II, Lisboa: Imprensa Nacional-Casa da Moeda, 1984, p. 451. 
Ao mesmo tempo, em processo inverso, a coroa e a igreja empreenderiam durante o século XVI, uma forte campanha a favor de um modelo de família hierarquizada e estável, baseada por um lado no aspecto "natural" do estado de casado/a com fim de constituir e engrandecer a família, e por outro numa insistente acção doutrinadora em torno do papel da mulher no seio e administração da casa ${ }^{37}$. Francisco de Monçon, por exemplo, interligava o ponto abordado anteriormente em torno do conselho da mulher, com o governo da esfera doméstica, sendo que no caso de uma princesa, isso passaria pela administração da sua casa e governo das mulheres da corte, das suas virtudes, ofícios e maneiras ${ }^{38}$.

O poder das mulheres na sociedade baseava-se e advinha assim, segundo alguns autores, da sua família e do lugar que esta ocupava na hierarquia social, numa rede de poder social, baseada na posse e distribuição de rendas, honras e bens ${ }^{39}$. Maria Paula Marçal Lourenço, por exemplo, define o conceito de rainha em Portugal com base na posse e usufruto dos bens, direitos e privilégios inerentes à esposa do rei e mãe da sua prole ${ }^{40}$. Nas Ordenações Afonsinas, dos 556 artigos, apenas 2 dizem respeito directamente às consortes reais ${ }^{41}$, havendo apenas outro em que se normatiza o cargo de ouvidor das terras das rainhas de Portugal ${ }^{42}$. Num desses artigos, afirma o monarca que é prática a atribuição de grandes doações às rainhas de Portugal, como resultado dos seus merecimentos e por "bem e virtude dos seus matrimónios" ${ }^{43}$.

${ }^{37}$ López-Cordón Cortezo, María Victoria - Familia, ..., cit., p. 123.

${ }^{38}$ BUESCU, Ana Isabel - Imagens do príncipe ..., cit., p. 219.

${ }^{39}$ MCNAMARA, Jo Ann - Women and Power Through the Family Revisited, in ERLER, Mary Carpenter e KOWALESKY, Maryanne (ed.), Gendering the Master Narrative: Women and Power in the Middle Ages, Nova Iorque: Cornell Unversity Press, 2003, p. 17-30, p. 19.

${ }^{40}$ Lourenço, Maria Paula Marçal - Ser rainha de Portugal nos alvores da modernidade, in Cadernos do noroeste, Vol. 20, No 1-2, 2003, p. 601-616, p. 613-615.

${ }^{41}$ Ordenações Afonsinas, Lisboa: Fundação Calouste Gulbenkian, 1984, Livro II, Título XXXIX: "Que as Raynhas, e os Iffantes nom dem Cartas de Privilegios a nenhumas pessoas", p. 290-292; Livro II, Título XL: "De como as Raynhas, e os Iffantes haõ d'usar das Juridiçooens nas Villas, e Terras, que lhes forem dadas per ElRey”, p. 293-300.

42 Ordenações Afonsinas, ..., cit., Livro I, Título VIII: "Do Ouvidor das terras da Rainha", p. 68-71.

${ }^{43}$ Ordenações Afonsinas, ..., cit., Livro II, Título XL: "De como as Raynhas, e os Iffantes haõ d'usar das Juridiçooens nas Villas, e Terras, que lhes forem dadas per ElRey", p. 293. 
A Casa da Rainha, no início da época moderna, juntamente com algumas outras casas senhoriais, dispunham de mecanismos de poder e fontes de rendimento, não só independentes da Casa do Rei, como também passíveis de distribuição, concorrendo por vezes com a coroa como "fonte de honras e mercês" ${ }^{44}$. Nesse sentido dizia D. Manuel à sua filha, que em 1521 partia para Saboia, que "Do governo e justiça de vosas terras que a voso careguo esteverem, vos encomemdo que tenhaes muito cuidado fazeemdo tudo com conselho de voso marido. E aveemdo vós de pôr pesoas que governem a justiça (...). E sempre trabalhares e procurares saber, quanto em vós for, como as taes pesoas ho fazem, e semdo necessário algum coregymento ou mudança de pesoa o averdes de fazer com conselho de voso marido" 45 .

A "casa", mais do que meramente um espaço físico, era uma unidade social, em que, no caso da família real, coexistiam interesses políticos, económicos e sociais em torno dos seus membros. A casa da rainha é de resto uma antítese da visão misógina e paternalista do poder. Ao mesmo tempo que se reprovava a presença feminina no governo e se esperava que esta se limitasse à sua "casa", dentro desta esperava-se a distribuição de rendas, graças e mercês, traduzindo-se isto no fim também numa forma de poder político, quando se tratava da Casa da Rainha ${ }^{46}$. A doação de bens entre marido e mulher era de resto um costume enraizado em Portugal desde, pelo menos, o século XIII, encontrando-se na chancelaria de D. Afonso III que era o marido obrigado a doar alguma herdade à sua mulher, que deveria reverter mais tarde para os seus filhos ${ }^{47}$.

No caso, por exemplo da mãe de D. Beatriz, D. Maria, aquando do seu casamento, D. Manuel comprometeu-se através do contrato de casamento a fornecer à sua segunda mulher as rendas de Montemor-o-Novo e Viseu, devendo receber as terras que tradicionalmente pertenciam às rainhas de

${ }^{44}$ CUNHA, Mafalda Soares da e MONTEIRO, Nuno Gonçalo - Aristocracia, Poder e Familia em Portugal, Séculos XV-XVIII, in Sociedade, Família e Poder na Península Ibérica. Elementos para uma História Comparativa, Lisboa: Edições Colibri / CIDEHUS - Universidade de Évora / Universidad de Murcia, 2010, p. 47-75, p. 48.

${ }^{45}$ Cit. por CARVALHO, José Adriano de Freitas - Pais e Nobres ..., cit., Vol. I, p. 263

${ }^{46}$ Ward, Jennifer C. - Women in Medieval Europe, 1200-1500, Harlow: Pearson Education, 2002, p. 116-122.

${ }^{47}$ Ordenações Afonsinas ...,cit., Livro IV, Título XIV: "Da Doaçom feita pelo marido aa molher, e pela molher ao marido", p. 81 . 
Portugal, quando falecesse D. Leonor, viúva de D. João $\mathrm{II}^{48}$, ao que se somava a renda que por contrato de casamento os seus pais se comprometiam a pagar-lhe para o seu mantenimiento no valor de 450 maravedis por ano $^{49}$, além do seu dote no valor de 200.000 dobras $^{50}$. Aquando da sua chegada a Portugal, D. Manuel doar-lhe-ia ainda o senhorio de Viseu e Torres Vedras ${ }^{51}$. Não possuindo o volume da casa da sua cunhada D. Leonor, viúva de D. João II, a casa de D. Maria não deixa no entanto de ser durante os seus anos de existência uma das mais importantes, talvez mesmo a mais importante, a seguir à do monarca, se se tiver em conta a importância das referidas "relações de força" existentes na esfera doméstica ${ }^{52}$. A casa desta rainha contaria à data da sua morte com 217 moradores, muitos deles recebendo tenças e mercês da coroa $^{53}$. Esta seria desmantelada em 1517 após a morte da sua titular, sendo reinstituída nesse mesmo ano em favor da filha mais velha dos monarcas, D. Isabel de Portugal ${ }^{54}$.

Estas práticas encontram-se testemunhadas por D. Manuel, ao pedir à sua filha que com as suas "criadas, e criados, tende muyto cuidado pera procurardes a todos o seu boõ encaminhamento e asy de os ajudardes e fazerdes mercê segundo seus serviços e necesidades, e primcipalmente aos que vos beem e fielmentee com amor vos servirem" 55 . Ao mesmo tempo instruia também o monarca português que "os irmãos e paremtes chegados ao duque voso marido sejam de vós [D. Beatriz] sempre homrados e favorecidos assim como os homrrados e homrradas da terra devem receber de vós muita homrra e gasalhado segundo as pessoas foreem. E quando por elles fordes

${ }^{48}$ RODRIGUES, Ana Maria S. A. - For the Honor of Lineage and Body: the Dowers and Dowries of Some Late Medieval Queens of Portugal“". in e-Journal of Portuguese History, Vol. 5, $\mathrm{n}^{\circ} 1,2007$. (http://www.brown.edu/Departments/Portuguese_Brazilian_Studies/ejph/ html/issue9/pdf/arodrigues.pdf, consultado em 2012.01.12), p. 10.

${ }^{49} \mathrm{Arq}^{\mathrm{O}}$. General de Simancas, Patronato Regio, Leg. 50, Doc. 32, F1. 8.

${ }^{50} \mathrm{Arq}^{\circ}$. General de Simancas, Patronato Regio, Leg. 50, Doc. 32, F1. 1.

${ }^{51}$ RODRIGUES, Ana Maria S. A. - For the Honor of Lineage..., cit., p. 10.

${ }^{52}$ EARENFIGHT, Theresa - Without the Persona of the Prince ..., cit., p. 8.

${ }^{53}$ SOUSA, António Caetano de - Provas da História genealogica da casa real Portugueza, Tm. II, Lisboa: Academia Real, 1742, p. 374-381.

${ }^{54}$ Para a constituição, funcionamento e servidores da casa da infanta Isabel de Portugal veja-se SILVA, João Eusébio - Estrela Clara de Aurora “: Isabel de Portugal (1503-1539). Infância e educação de uma infanta de Portugal, Tese de mestrado apresentada à FCSH-UNL (Set. 2010), p. 108-162.

${ }^{55}$ Cit. por CARVALHO, José Adriano de Freitas - Pais e Nobres..., cit., Vol. I, p. 264. 
requeridos pera os ajudardes em alguns requerymentos ou favores com voso marido e cousas que lhe cumpram, parece-nos que devees folgar de o fazer, em maneira que todos conheçam de folgardes e desejardes seu bem"56.

Dizia ainda a D. Beatriz que "De vosa fazenda si ha me parece que devees trabalhar de ter boõ cuidado aproveytamdo-a e olhamdo por ela quamto vós beem poderdes (...). E primcipalmemte vos encommendo que trabalhees por que a vosa despesa seja meenos, o mais que possa ser nam leixando de compryr com o neceSÁrio a vosa onra e estado, do que for a remda que tiverdes" $" 57$.

Desta fazenda faria parte o dote e a dotação acordados no seu contrato de casamento, segundo o qual D. Manuel pagaria 150.000 ducados, dos quais 50.000 diziam respeito a jóias, ao que se deveria acrescentar os custos da armada que levaria a infanta a Saboia, assim como os atavios e paramentos necessários à câmara de D. Beatriz ${ }^{58}$. A isto deviam-se somar 20.000 cruzados para a dotação da infanta tornada duquesa ${ }^{59}$. A estes o seu cunhado Carlos V acrescentaria mais tarde os condados de Asti e Cerva, com o titulo de Vigária do Sacro-Império, tendo isto sido pedido pela própria D. Beatriz, segundo alguns autores ${ }^{60}$.

${ }^{56}$ Cit. por CARVALHO, José Adriano de Freitas - Pais e Nobres..., cit., Vol. I, p. 262.

${ }^{57}$ Cit. por CARVALHO, José Adriano de Freitas - Pais e Nobres..., cit., Vol. I, p. 264.

${ }^{58}$ VITERBO, Francisco de SOUSA - O dote de D. Beatriz ..., cit., p. 8.

${ }^{59}$ Existe no entanto indicação que D. Beatriz nem sempre terá usufruído facilmente das rendas que lhe eram devidas. D. João III, por exemplo, mostrava-se preocupado com o facto de a sua irmã Beatriz não receber as suas rendas como devia e se seria bem tratada no seu ducado, questionando o seu embaixador nesse sentido (Relações de Pêro de Alcáçova Carneiro em que ele e seu pai, António Carneiro, serviram de secretários (1515-1568), Andrada, Ernesto de Campos de (Revisão e Anotações), Lisboa: Imprensa Nacional, 1937, p. 128-129).

${ }^{60}$ CLARETA, Gaudenzio - Notizie storiche ..., cit., p. 74. Cedidos por Francisco I após os tratados de Cambrai, estes dois territórios voltavam assim para a posse dos duques de Saboia, o que terá causado jubilo entre a população (CLARETA, Gaudenzio - Notizie storiche ..., cit., p. 73). Torna-se no entanto curioso a doação ter sido feita a D. Beatriz como cunhada do imperador a título vitalício e não ao seu marido que detinha direitos dinásticos sobre a posse destes territórios. De resto, como o abade de Brantôme notaria, existem indícios de uma relação de carinho entre o imperador e a sua cunhada. Em 1532 por exemplo, Carlos V em carta a Carlos III diria "Mon cousin, si ce nestoit lespoir que jay de veoir madame ma seur, vostre femme, et que espère, que, puisquelle est enterre, son mal ne sera grand, je le sentiroye au double, si men a il austant despieu que, si j e leusse en moy mesmes" (LANZ, Karl - Correspondenz des Kaisers Karl V, Vol. II, Leipzig: F. A. Brockhaus, 1845, p. 53). 
Foi já notado pela historiografia como o séquito de D. Beatriz deteve um grande peso na sociedade de Saboia ${ }^{61}$. Para os seus servidores D. Beatriz pediria regularmente graças e mercês, quer em Saboia quer em Portugal, casando muitas das suas damas com fidalgos saboianos, como D. Mécia de Bragança casada com René, conde de Challant, cumprindo assim D. Beatriz outra das Instruções de D. Manuel ${ }^{62}$.

Como já foi dito, a esfera de domínio feminino assentava em grande parte no poder do privado e dos labores domésticos, sendo que isto era algo que no caso de uma mulher pertencente à elite social do reino se revestia de um significado também ele público, particularmente no caso de mulheres pertencentes à casa real, que detinham um poder representativo aliado ao seu carácter de membros da esfera de vida privada do monarca ${ }^{63}$, algo a que a riqueza e bom funcionamento das suas casas não estavam de todo alheados. Era aliás a capacidade de redistribuição de "riqueza" que instituía a importância maior ou menor de uma casa e do seu titular ${ }^{64}$. Diz-se de D. Maria que acabando de solicitar e conseguir algo do seu marido, logo lhe pedia mais, tendo certa vez D. Manuel dito "Não fiz já muitas cousas que me pedistes?" Ao que a rainha lhe terá retorquido que "Os Reys nunca hão de cansar de fazer bem" ${ }^{\prime 5}$.

${ }^{61}$ Alguns testemunhos dão indicação, por exemplo, que na cerimónia de casamento em Turim estariam cerca de 5.000 portugueses, nunca se tendo visto tantos ornamentos e tanto luxo, numa comitiva que mostrava todo o poderio e luxo que a Africa e a India de D. Manuel podia oferecer (CLARETA, Gaudenzio - Notizie storiche ..., cit., p. 44).

${ }^{62}$ D. Mécia, filha de D. Dinis de Bragança, como tal sobrinha de D. Jaime duque de Bragança e prima de D. Beatriz. D. Manuel dela diria nas suas Instruções: "vos encomemdo que tenhaes dela muyto cuidado asy pera receber de vós toda onra e favor como seja rezam como pera a mandardes porém de todo o que lhe for necessário de vestido e de todas outras cousas asy como vos parecer que se deve fazer e que ella deve dandar. E sobre todo vos encomemdo muyto que trabalhes quanto a vós seja posível por a casar e onrrar e encaminhar honradamente como ella merece por ser tam chegada a noso sangue“. cit. por CARVALHO, José Adriano de Freitas - Pais e Nobres..., cit., Vol. I, p. 265.

${ }^{63}$ Ward, Jennifer C. - Women in Medieval Europe, ..., cit., p. 111.

${ }^{64}$ CUNHA, Mafalda Soares da-Nobreza, Rivalidade e clientelismos na primeira metade do Século XVI. Algumas reflexões, in Penélope, $\mathrm{n}^{\circ}$ 29, 2003, p. 33-48, p. 33.

${ }^{65}$ ANJOS, Luís dos, Jardim de Portugal, Coimbra, Nicolau CARVALHO, 1626, p. 339. 


\section{4. da onestidade e guarda e vertude: A imagem de mulher honrada, devota e virtuosa}

"Da onestidade e guarda e vertude de vossa casa vos peço filha que tenhes muito grande cuidado por ser cousa que tamto toca a voso louvor, e a que tamt obrigaçam temdes" ${ }^{\prime 6}$. Com estas palavras D. Manuel incitava a sua filha a preservar três dos principais traços de personalidade que uma perfeita princesa quinhentista deveria ter. A imagem, muitas vezes estilizada dos registos cronísticos em torno das consortes de Portugal, em registos semi-hagiográficos, a maior parte das vezes, apresenta-nos exactamente estes traços, ignorando ou omitindo individualidades, defeitos e capacidades destas mulheres. Os filhos de D. Manuel e D. Maria parecem de resto ter reunido grandes qualidades, levando ao autor do Carro de Donas a descrevê-los como “ (...) espejos y lumbreras de toda christandad, que assi como son grandes y en poder y alteza son sublimados en virtudes e muy gran nobleza"67.

Esta instrução poderá ser no entanto central no caso de D. Beatriz. A acreditar nas já referidas fontes, segundo as quais D. Beatriz possuía uma certa altivez e soberba, seria natural que o seu pai lhe incitasse a práticas mais de acordo com a ideia de majestade feminina, virtuosa e recatada. Num episódio anedótico passado na corte manuelina entre as duas filhas de D. Manuel é-nos dito que: "Querendo el-rei casar uma filha com o duque de Saboia, tocou nisso a D. Isabel, que era a mais velha, (...) e ela disse que havia de ser rainha ou beguina [freira]. E determinando-se disso el-rei então de casar a mais moça [D. Beatriz] (...); e chegando já o tempo de partida, estando as irmãs uma noite ambas, quando se quiseram recolher, disse a mais moça à outra em maneira de graça: - Vossa alteza fique com vossa reverência. E ela respondeu-lhe: - E vossa alteza vá com vossa senhoria"68.

${ }^{66}$ Cit. por CARVALHO, José Adriano de Freitas - Pais e Nobres..., cit., Vol. I, p. 263.

${ }^{67}$ Cit. por CLAUSSEL NÁCHER, Cármen - Carro de las Donas (Valladolid, 1542): Estudio Preliminar y Edición Anotada, Tese de Doutoramento apresentada ao Dept ${ }^{\circ}$. de Literatura espanhola, Univ. Autónoma de Barcelona, (http://www.tdx.cesca.es/TDX-0608105-110729/\#documents, consultado em 2010-09-01), vol. II, p. 379.

${ }^{68}$ Ditos portugueses dignos de memória: história intima do século XVI, SARAIVA, José Hermano (anotações e comentários), Mem-Martins: Europa-America, 1980, p. 240. 
Para além de nos apresentar um raro momento do quotidiano feminino da família real, este relato apresenta-nos acima de tudo duas infantas com plena consciência da sociedade em que viviam e do lugar que nela ocupavam ${ }^{69}$.

Mais de acordo com a imagem de perfeita consorte e rainha encontramos a caridade e a devoção, confundindo-se estas neste período com o virtuosismo e honestidade de uma mulher, sendo, parte integrante do quotidiano feminino na Época. Do governo doméstico, apanágio feminino como foi referido no ponto anterior, faria parte a manutenção da honra e virtude das mulheres que a integravam, cabendo às consortes dos monarcas a preservação da moral e dos bons costumes no seio da corte e da família ${ }^{70}$. Não querendo adentrar-nos no papel da educação que abordaremos de seguida, importa no entanto salientar o papel pedagógico do exemplo. No contexto do humanismo o modelo detinha um grande peso, não só a nível estilístico (quer literário quer na arte), como também pedagógico, através do uso de figuras exemplares que servissem de imagem e inspiração para uma conduta correcta ${ }^{71}$, sendo assim imprescindível na educação de uma jovem, particularmente os exemplos familiares.

Deve-se assim recordar a imagem que a cronística legou da segunda mulher de D. Manuel, mãe de D. Beatriz, filha por sua vez de Isabel a Católica, modelo para as suas descendentes femininas. Das "práticas devotas, aos actos de caridade, á fundação e protecção de instituições religiosas, à sua responsabilidade materna e, significativamente à sua discrição política"72,

${ }^{69}$ No caso de Isabel de Portugal porém estes traços da sua personalidade altiva seriam tratados quase como qualidades pela cronística, ao contrário da sua irmã. Esta infanta, que teria como lema antes de casada Aut Caesar aut nihil, (significando a sua determinação em casar ou com Carlos V ou com ninguém), é descrita na cronística como aspirando "a grandeza de alto estado" (OSÓRIO, Jerónimo - Da vida e feitos de el-rei D. Manuel, Lisboa: Quidnovi, 2004, p. 62), "senhora de grande syso e acabada em perfeita descryção e prudência sobre todas a cortesia" (CORREIA, Gaspar - Crónicas ..., cit., p. 162) e "fermosa, \& muito isenta de sua condiçam, $\&$ de tam altos pensamentos que presopos de nam casar senam com o mor senhor da cristandade" (GÓIS, Damião de - Crónica do felicissimo ...,cit., Pt I, Liv. LXXV, fl. 74).

${ }^{70}$ BUESCU, Ana Isabel - Imagens do príncipe ..., cit., p. 219.

${ }^{71}$ HOWE, Elizabeth Teresa - Education and Women in the Early Modern Hispanic World, Aldershot: Ashgate Publishing, 2008, p. XI.

${ }^{72}$ FERNANDES, Maria de Lurdes - D. Maria, mulher de D. Manuel: Uma face esquecida da corte do Venturoso, in Revista da Faculdade de Letras "Línguas e Literaturas», Porto, $\mathrm{XX}, \mathrm{n}^{\mathrm{o}} 1,2003$, p. 105-116, p. 108. 
a imagem que nos foi legada de D. Maria foi a de uma consorte modelar e submissa daquele que se queria o maior monarca da cristandade.

Como a sua mãe havia feito, D. Maria adoptaria na corte portuguesa o papel de educadora não só dos seus filhos como também das suas damas e moças de câmara, que seriam mais de $80^{73}$. O modelo fornecido pela sua mãe, Isabel, a Católica, rainha de Castela seria transposto para as suas próprias filhas, ocupando-as nas mesmas práticas e hábitos do seu quotidiano como rainha, ensinando-as a coser e a bordar ${ }^{74}$.

Era sem dúvida D. Maria uma mulher piedosa, "ornada de excellentes virtudes, e muy devota", atribuindo esmolas e socorrendo infelizes ${ }^{75}$. D. Manuel instruía também a sua filha para que "As religiosas e religiosos que esteverem na conservância [sic] e em vertude vyverem vos encommendo que recebam de vós toda caridade e esmola que beem poderdes quando vos vierem requerer e souberdes que tem diso necesidade. E asy folgay de os ajudardes com voso marido no que vos requererem, e ouverem mester vosa ajuda com elle"76. De resto a sua primeira instrução dizia respeito precisamente à devoção, pedindo a D. Beatriz que tivesse "gramde cuydado de por neemhuma cousa deste mundo quanto vos seja possível, nam façaes cousa com que ofendaes a Noso Señor per que elle teenha cuydado de vós pello tamto verdes mester, alem da necesidade e obrigaçam geral que todos temos" $" 77$.

Acerca dos serviços religiosos dizia D. Manuel que "A orden do serviço da vosa capela e ouvyr os ofícios devynos segundo fostes criada vos encomemdo que tenhaes muito cuidado em tal maneira que asy neste como em todas as outras cousas de vertude e devaçam se veja que cada dia vão em vós em crecimento, e isto vos emcomemdo muito, que tenhaes muy grande cuidado "78. Neste ponto era conhecida a fama da capela do rei de Portugal e

${ }^{73}$ FERNANDES, Maria de Lurdes - D. Maria, ..., cit., p. 110.

${ }^{74}$ VALES FAILDE, Javier - La emperatriz Isabel, Madrid, in Revista de Arch. Bibli. y Museos, 1917, p. 97.

${ }^{75}$ SOUSA, António Caetano de - História genealogica ..., cit., p. 135.

${ }^{76}$ Cit. por CARVALHO, José Adriano de Freitas - Pais e Nobres..., cit., Vol. I, p. 263.

${ }^{77}$ Cit. por CARVALHO, José Adriano de Freitas - Pais e Nobres ..., cit., Vol. I, p. 261-262.

${ }^{78}$ Cit. por CARVALHO, José Adriano de Freitas - Pais e Nobres..., cit., Vol. I, p. 264. 
do seu serviço ${ }^{79}$, sendo este um espaço por excelência para a representação do poder da coroa na corte manuelina. $\mathrm{O}$ modelo da capela real portuguesa terá sido assim levado por D. Beatriz para Saboia ${ }^{80}$, juntamente com os seus hábitos musicais, viajando com a infanta uma orquestra composta três violas de arco, uma citara, oito trombetas, seis charamelas e seis tambores ${ }^{81}$. No seu enxoval levava consigo vários objectos que não só demonstravam a riqueza da coroa portuguesa como também remetiam para hábitos de devoção. Assim encontramos duas taças grandes douradas com uma coroa, quatro esferas e quatro cruzes de Cristo na base com a representação das sete virtudes e dos sete pecados no topo; um porta-paz de prata dourada representando Nossa Senhora com o menino; uma cruz de prata dourada esmaltada de âmbar; um rosário de ouro com as contas de âmbar; mais uma infinidade de objectos de culto cuja listagem seria muito extensa ${ }^{82}$. Alguns destes objectos seriam herança da sua mãe, como talvez um "gomil de prata branco lavrado de meas canas com hum escudo das armas de Portugal e Castela no bico" $" 83$.

Encontramos assim nas Instruções, por um lado um pai a incitar a sua filha às práticas devotas e honestas, e por outro, um monarca a transmitir a imagem paradigmática de uma consorte honrada e virtuosa, não descurando a importância do luxo e da representação como símbolos de poder. Se a sua mulher D. Maria era irmã de S. Francisco por devoção, sendo enterrada com o hábito e pedindo no seu testamento que no seu cortejo fúnebre não se levassem tochas, apenas uma lanterna para iluminar o caminho ${ }^{84}$,

${ }^{79}$ VITERBO, Francisco de Sousa - Artes e artistas em Portugal. Contribuições para o estudo das artes e industriaz portuguezas, Lisboa: Livraria Ferreira, 1892, p. 177.

${ }^{80}$ No caso da sua irmã mais velha, Isabel de Portugal, esta transposição dos modelos, não só da capela real portuguesa como da casa da rainha, para a corte de Carlos V levantaria algumas contestações, de resto antecipadas por D. João III que no seu regimento para Rui Telles, mordomo da imperatriz diria que "o modo do serviço de ca ser tanto melhor do que nenhum outro", devendo Rui Teles dirigir-se ao imperador e lembrar-lhe que esse é o modo em que a imperatriz se criou e alterá-lo iria desgostá-la (Relações de Pêro de Alcáçova Carneiro ..., cit., p. 256).

${ }^{81}$ VITERBO, Francisco de Sousa - O dote de D. Beatriz ..., cit., p. 11.

${ }^{82}$ Publicado por SOUSA, António Caetano de-Provas da História genealogica da casa real Portugueza, Tm. II, Lisboa: Academia Real, 1742, p. 445-489.

${ }^{83}$ SOUSA, António Caetano de - Provas da História ..., cit., p. 447.

${ }^{84}$ CORREIA, Gaspar-Crónicas ..., cit.,p. 124. 
representando o modelo de rainha virtuosa, despojada de honras perante a morte, este modelo de devoção e despojamento condizia com o de rainha.

\section{Como filhos vossos devem de seer e netos meus e de vossa may: a educação da prole e a perpetuação dinástica}

Foi referido anteriormente a importância do exemplo no contexto do humanismo, importa agora referir esse outro papel tão central de uma mulher, rainha ou não, no contexto social: o de mãe. Perpetuadora dinástica, mestre e modelo das suas filhas, o papel de consorte régia baseava-se em grande parte na sua capacidade reprodutora e continuadora da linhagem.

Nas suas Instruções D. Manuel afirma-o de forma taxativa: "a Nosso Señor que vos [a D. Beatriz] dee filhos, como nelle esperamos que seja, e muy cedo, devenos de lembrar a criaçam delles seja em toda vertude e boõ emssyno como filhos vossos devem de seer e netos meus e de vossa may" ${ }^{\prime 2}$. Nesta curta frase pode-se assim comprovar o papel determinante que, não só a educação dos filhos tinha no caso de uma infanta, como também a forte componente de pertença linhagística na vida dos membros da família real. Se da educação de um príncipe dependia em grande medida um bom governo de um reino, da educação de uma princesa dependia o bom governo de uma casa, neste caso real ${ }^{86}$, estando de resto ambos os conceitos profundamente interligados na concepção política da Idade Moderna ${ }^{87}$.

No século XIV Francisco Eiximenis havia publicado o seu Libro de Las Dones, em que pretendia acima de tudo apresentar modelos de virtude capazes de mostrar às jovens o que se esperava delas enquanto mulheres e mães, não constituindo propriamente a delineação de um plano de estudos baseado no ensino ${ }^{88}$. Já para Cristina de Pisan, considerada por alguns

${ }^{85}$ Cit. por CARVALHO, José Adriano de Freitas - Pais e Nobres..., cit., Vol. I, p. 264.

${ }^{86}$ BELY, Lucien - La Société des Princes (XVI - XVIII ${ }^{e}$ siècles), Paris: Fayard, 1999, p. 87.

${ }^{87}$ Para a concepção do sistema administrativo do Antigo Regime baseado no modelo de economia doméstica ver FRIGO, Daniela - «Disciplina Rei Familiariae»: a economia como Modelo Admnistrativo de Ancien Régime“, in Penélope.Fazer e desfazer a história, $\mathrm{n}^{\circ} 6,1991$, p. 47-62.

${ }^{88}$ BENASSAR, Bartolomé - A cama ..., cit., p. 217. 
autores como uma das primeiras vozes feministas da história ${ }^{89}$, a educação feminina deveria ser igual à masculina, defendendo quase solitariamente que a capacidade intelectual das mulheres não era de todo inferior à dos homens ${ }^{90}$.

A afirmação de uma sociedade de corte não permitiria de resto uma continuada exclusão das mulheres da cultura letrada. Castiglione, na sua obra Il Cortegianno (1528), afirmaria já no século XVI que nenhuma corte podia dispensar o ornamento e a graça femininas ${ }^{91}$, o que vinha, aliás, na linha de protagonismo crescente da mulher nas cortes régias e senhoriais da Idade Média. Ao mesmo tempo Juan Luís Vives, afirmava que a maior parte dos vícios e pecados das mulheres advinham da sua falta de instrução, publicando em 1523 De Institutio Feminae Christian. Defendendo a primazia intelectual masculina, Vives não deixaria no entanto de valorizar a educação feminina $^{92}$, não pretendendo criar um modelo de virgem como haviam feito S. Ambrósio e S. Jerónimo, mas um modelo de donzela, preparada para o seu futuro papel de esposa e de mãe ${ }^{93}$.

Daqui a naturalidade de se encontrar associado ao papel de mãe, o de modelo. Acerca do uso do modelo e do exemplo, é curioso referir que o Renascimento, que trouxe consigo um novo gosto pelos clássicos, encontrou na mitologia deusas como Diana, activa e determinada, ao mesmo tempo que relembrou as virtudes de Deméter, Hera e Cibeles, preferindo estas a Atenas ou Perséfone, conhecidas pelos seus atributos intelectuais ${ }^{94}$.

Cabia no fim aos príncipes zelar pela educação das suas filhas, que se propunham a oferecer em casamento no xadrez matrimonial da Europa moderna, tendo em conta algo que os tratadistas humanistas não equacionavam nas suas obras, a importância do esplendor e da aparência numa sociedade de corte cada vez mais ritualizada, onde estes factores

${ }^{89}$ Acerca do papel da mulher neste período deve-se consultar a importante obra de KING, Margaret - A mulher do Renascimento, Lisboa: Presença, 1994.

${ }^{90}$ BENASSAR, Bartolomé - A cama ..., cit., p. 217.

${ }^{91}$ BENASSAR, Bartolomé - A cama ..., cit., p. 218.

${ }^{92}$ BENASSAR, Bartolomé - A cama ..., cit., p. 218.

${ }^{93}$ FERNANDES, Maria de Lurdes - Espelhos, Cartas e Guias. Casamento e Espiritualidade na Península Ibérica. 1450-1700, Porto: Instituto de Cultura Portuguesa, Faculdade de Letras da Universidade do Porto, 1995, p. 197.

${ }^{94}$ LÓPEZ-CORDÓN, Maria Victoria - La conceptualizacion de las Mujeres en el antiguo regimen: Los Arquetipos Sexistas, in Manuscrits, $\mathrm{n}^{\circ} 12$, 1994, p. 79-107, p. 89. 
eram reflexo de poder ${ }^{95}$ e parte determinante nos matrimónios dinásticos, tão importantes na política das grandes casas ${ }^{96}$.

Como terá sido assim a educação da prole de D. Manuel e de D. Maria? Se no caso de D. João, herdeiro do trono, encontramos o nome de alguns mestres e das suas práticas enquanto criança e aluno, pouco se encontra para os demais filhos dos reis de Portugal, principalmente no caso das infantas. No entanto não se pode assumir isto como uma falta, não sendo plausível que um rei que se queria dos maiores da cristandade, cujo quotidiano passava por uma ostentação permanente de riqueza e poder, não desse importância à educação dos seus filhos ${ }^{97}$, que representariam mais tarde Portugal nas cortes estrangeiras. Se na formação de um príncipe herdeiro entravam os tratados clássicos de história e política, no caso de uma infanta deveriam entrar a doutrina, a devoção e os labores domésticos. O luxo, a cultura e o requinte da corte de D. Manuel, certamente se reflectiram na educação dos príncipes filhos do monarca ${ }^{98}$. Na educação dos filhos terá D. Maria marcado também presença constante e fundamental ${ }^{99}$. Tendo em conta a referida imagem da segunda mulher de D. Manuel como virtuosa, devota e honrada rainha, decerto os seus filhos terão sido educados "em toda vertude e boõ emssyno" como D. Manuel prescrevia em 1521 à sua filha que fizesse ${ }^{100}$.

No caso melhor documentado de D. João, encontramos o testemunho, de certa vez, em que após praticar uma má acção, foi levado à câmara do rei, onde este se encontrava a sós com D. Maria, sendo admoestado e castigado fisicamente pelo pai ${ }^{101}$. Damião de Góis, que a conheceu em criança no paço,

${ }^{95}$ BENASSAR, Bartolomé - A cama ..., cit., p. 218-219.

${ }^{96}$ BELY, Lucien, La Société des Princes ..., cit., p. 192.

${ }^{97}$ Sobre a educação dos príncipes, veja-se BUESCU, Ana Isabel - Educar o príncipe no século XVI. Modelos, práticas e representações", in BUESCU, Ana Isabel, Na corte dos reis de Portugal. Saberes, ritos e memórias, Lisboa: Colibri, 2010, p. 11-51.

${ }_{98}$ VITERBO, Francisco de Sousa - Artes e artistas ..., cit., p. 177.

${ }^{99}$ D. Maria enquanto infanta terá aprendido, além das letras, música, tocando clavicórdio, assim como seria fluente em latim tendo Andrés de Miranda como mestre (BENASSAR, Bartolomé - A cama ..., cit., p. 221). Recorde-se que havia sido educada junto da sua irmã Catarina, futura rainha de Inglaterra, cuja cultura e educação eram admiradas na época por toda a Europa levando autores como Luís Vives a nomeá-la como modelo de educação e de mulher (VIVES, Juan Luís - Instruccion de la muger christiana, Madrid: Impr. de Don Benito Cano, 1793, p. 21).

${ }^{100}$ Cit. por CARVALHO, José Adriano de Freitas - Pais e Nobres..., cit., Vol. I, p. 264.

${ }^{101}$ BUESCU, Ana Isabel - D. João III ..., cit., p. 59. 
afirma na sua crónica que D. Maria, “(...) castigava o príncipe, e Infantes seus filhos quando o mereciam, sem perdoar a nenhum deles, aos quais todos sempre mostrou igual amor, sem nisso fazer outra diferença que da precedência da idade de que cada um era"102. É interessante de resto a clara preocupação por parte das fontes em vincar a proximidade de D. Manuel (refundador da dinastia) aos seus filhos, assim como a unidade entre os mesmos. Anos antes o mesmo sucedia com D. João I, fundador da dinastia de Avis, a quem a cronística havia ostensivamente veiculado a proximidade entre pais e filhos, como forma de, com base na unidade familiar, legitimar uma dinastia de origem bastarda ${ }^{103}$.

Este ponto remete para outra das directivas fornecidas por D. Manuel à sua filha: a ideia de pertença familiar e o honrar da linhagem. Assim pedia à sua filha que se lembrasse das suas Instruções e que tivesse "cuidado e lembramça pera as averdes de fazer e compryr como merece o muito amor que vos tenho e volas digo em tal maneira que com elas primeiramente ganhes a bençam de Noso Señor, e despois de vosas avós a rainha de Castela e minha may que tam vertuosas e eccelentes princezas foram, e asy a minha e há de vosa mãy.“104

A importância dada, como se viu, à honra e à virtude, assumia uma dimensão central no caso dos membros femininos da família real, fruto do seu papel como perpetuadoras da linhagem, base sobre a qual assentava o matrimónio. Recorde-se que numa sociedade patriarcal como era a do século XVI, em que os bens e títulos passavam de pai para filho, era necesário garantir a legitimidade dos filhos, pelo que a virgindade de uma princesa era situação sine qua non para o seu matrimónio ${ }^{105}$. Afonso X nas suas Siete Partidas, obra central no pensamento político peninsular durante a Idade Média e início da Idade Moderna, afirmava que, no que diz respeito à escolha de uma consorte, “(...) el rey debe catar que aquella con

${ }^{102}$ GÓIS, Damião de - Crónica do felicissimo ..., cit., Pt IV, Cap. XIX, fl. 26-26v.

${ }^{103}$ FONSECA, Luís Adão da - Política e cultura nas relações luso-castelhanas no século XV, in Peninsula: Revista de Estudos Ibéricos, Porto, n. ${ }^{\circ}$ 0, 2003, p. 53-61, p. 55.

${ }^{104}$ Cit. por CARVALHO, José Adriano de Freitas - Pais e Nobres..., cit., Vol. I, p. 265.

${ }^{105}$ BARRANCO, Margarita Garcia - Antropologia histórica de una elite de poder: Las reinas de España, Granada, tese de doutoramento apresentada à Faculdade de Letras da Universidade de Granada, 2007 (texto policopiado), p. 240. 
quien casare haya en sí quatro cosas; la primera que venga de buen linage, la segunda que sea fermosa, la tercera que sea bien costumbrada, la quarta que sea rica;(..." ${ }^{\text {"106 }}$. O primeiro dos pontos referidos, imprescindível no que diz respeito à escolha de uma consorte régia, remete para os dois aspectos centrais da vida social e política presentes nas palavras de D. Manuel: o conceito de família e de linhagem.

Os afectos familiares e sociais no início de Quinhentos eram baseados na família como unidade dentro da qual o indivíduo se inseria. Ao estudar o papel dos afectos na sociedade e na política da Época Moderna, Pedro Cardim constatou que no seio da família existia um relacionamento essencialmente afectuoso, particularmente notório no relacionamento entre o chefe da família e os seus filhos ${ }^{107}$. Acerca da amizade e solidariedade no seio familiar, D. Duarte dizia à rainha $\mathrm{D}$. Leonor no seu Leal Conselheiro que "a pratiquey com vosco, como bem sabees, e com EIRey e a Raynha meus Senhores, Padre e Madre, cujas almas Deos aja, (...); e sempre lealdade pera boo regymento da casa he grande e pryncipal fundamento" 108 . Os filhos dos monarcas portugueses serviriam de exemplo e imagem idealizada, ou não, de como deveriam ser as relações e as características virtuosas presentes no seio de uma família. Como já foi referido por diversos autores, desde o século XV a coroa portuguesa apostou numa acção de legitimação da dinastia de Avis baseada na exemplaridade da mesma, apoiada pela cultura através da cronística, que passava por sua vez pelas imagens de família unida, família santa e família culta ${ }^{109}$, apesar de essa imagem nem sempre corresponder, como a história comprova, à realidade.

Esta ideia de amor entre familiares era algo que, muitas vezes ignorado pela historiografia, constituía o pilar sobre o qual se construía o modelo de casa e família, base como foi referido do sistema social no início da época moderna. O poder dos afectos estendia-se assim aos diversos campos da

${ }^{106}$ ALFONSO X - Las Siete Partidas del Rey Don Alfonso el Sabio, Tm. II, Madrid: Academia Real de la Historia- Imp. Real, 1807, Partida II, Titulo VI, Lei I, p. 47-48.

${ }^{107}$ CARDIM, Pedro - O poder dos afectos. Ordem amorosa e dinâmica política no Portugal do Antigo Regime, Lisboa, Dissertação de Doutoramento apresentada à FCSH-UNL, 2000 (texto policopiado), p. 210.

${ }^{108}$ PORTUGAL, Duarte de - Leal conselheiro, o qual fez dom Duarte: Seguido do livro da ensinança de bem cavalgar toda sella, Paris, J.P. Aillaud, 1842, p. 492.

${ }^{109}$ FONSECA, Luís Adão da - Política e cultura ..., cit., p. 61. 
sociedade, extravasando a esfera doméstica, desempenhando um papel fundamental nas relações sociais e políticas ${ }^{110}$. Este modelo baseado na consciência de pertença a uma família e na ideia de honrar e perpetuar a mesma, detinha assim um papel determinante na vida de uma infanta de Portugal, sendo parte fundamental da sua identidade, como se pode ver nas instruções de D. Manuel. Segundo António Manuel Hespanha “O amor dos pais pelos filhos, superior a todos os outros, funda-se no sentimento de que os pais se continuam nos filhos. Estes são, assim, uma extensão da pessoa que lhes dá o ser, ou seja, são a mesma pessoa" ${ }^{111}$.

Exemplo disso pode ser visto no testamento quer do rei de Portugal, quer da sua segunda mulher D. Maria, Rainha de Portugal, infanta de Castela, como se intitulava no seu testamento ${ }^{112}$, pedia assim que as suas filhas não se casassem a não ser com reis ou filhos de reis e que, não sendo isto possível, se tornassem freiras antes a casarem-se com alguém do reino, dependendo disso a sua bênção às filhas ${ }^{113}$. A mesma disposição seria repetida por D. Manuel no seu testamento de 1517, dispondo que caso existisse a possibilidade de se casarem no estrangeiro o seu herdeiro deve assegurar-se que "seja cousa de suas honras e de maneira que ellas casem como fillas de quem sam no estado", caso contrário seria preferível servirem Deus ${ }^{114}$. Esta ideia de pertença e grandeza familiar era assim algo não só natural como imprescindível quando se tratava de uma família real, sendo a memória dos antepassados algo que se perpetuava no ideal de engrandecimento da linhagem ${ }^{115}$.

${ }^{110}$ CARDIM, Pedro - Amor e Amizade na Cultura Política dos Séculos XVI e XVII, in Lusitânia Sacra, 2a série, 11, 1999, p. 21-57, p. 45.

${ }^{111}$ HESPANHA, António Manuel - Carne de uma só carne: para uma compreensão dos fundamentos histórico-antropológicos da família na época moderna, in Análise Social, vol. XXVIII (123-124), nº. 4-5, 1993, p. 951-973, p. 955.

${ }^{112}$ (As) Gavetas ..., cit., vol. VI, Gav. XVI, 2-1, p. 103.

${ }^{113}$ (As) Gavetas ..., cit., vol. VI, Gav. XVI, 2-1, p. 108-109.

${ }^{114}$ (As) Gavetas ..., cit., Vol. VI, Gav. XVI, 2-1, p. 127-128.

${ }^{115}$ Acerca da sua filha Maria, D. Isabel de Portugal diria anos mais tarde, por exemplo, no seu testamento "cuando la ynfante fuere para cassar no habiendo deser ella herdiera en outra parte por su descanso y consolacion della y porque yo se la diferencia que hay en las vidas las casse en Portugal que para ella sera mucho mejor que notra parte que sea mayor señora y así le encomiendo al principe y aella cuanto puedo" ( $\mathrm{Arq}^{\circ}$. General de Simancas, Patronato Regio,Leg, 30, Doc. 25). 
Esta ideia de pertença familiar teria um papel determinante na vida de D. Beatriz, a quem D. Manuel endereçava as suas Instruções. Exemplos disso terão sido as movimentações motivadas pela invasão dos territórios do ducado de Saboia por Francisco I, em que as relações familiares se apresentaram como centrais a nível diplomático. Numa das poucas cartas da sua irmã D. Isabel para o rei de Portugal em que se encontra uma componente mais pessoal, a imperatriz informa o irmão que recebeu correspondência de D. Beatriz ${ }^{116}$, pedindo ajuda para os duques de Saboia aquando a invasão dos seus territórios, o que os levara ao exílio, levando este acontecimento a fortes movimentações políticas de D. Isabel que reflectem a sua preocupação com o destino da sua irmã, levando-a a rogar a Carlos V que tomasse em consideração os laços familiares na solução a encontrar, referindo que “(...) les deviera bastar el trabajo pasado de la muerte del hijo, sin ver perder y destruir agora todo su estado" 117 . De resto esta infanta de Portugal, filha de D. Manuel e D. Maria possuía na sua câmara uma série de retratos familiares, nomeadamente retratos dos reis de Portugal (sem identificar se se trataria de D. Manuel e D. Maria ou de D. João III e D. Catarina), de D. Luís e D. Fernando e de uma infanta sem identificação ${ }^{118}$, que teriam não só uma componente afectiva como um objectivo político e social ao

${ }^{116}$ Após informar que de si não tem novidades a não ser que se encontra bem de saúde, Isabel de Portugal informa D. João III que recebeu novas de Saboia. ((As) Gavetas ..., cit., Vol. VIII, Gav. XVIII, 2-36, p. 232).

${ }^{117}$ MAZARIO COLETO, Maria del Carmen - Isabel de Portugal. Emperatriz y Reina de España, Madrid: Consejo Superior de Investigaciones Cientificas, 1951, p. 144. Luís de Saboia morreu em Madrid a 25 de Dezembro de 1535, durante uma justa, sendo aí educado junto da sua tia e do seu primo futuro Filipe II (SOUSA, António Caetano de - História Genealogica ..., cit.,vol. III, p. 175). Mesmo após a morte de D. Beatriz, Isabel de Portugal continuaria a honrar os seus descendentes com a estima que havia dedicado à sua irmã, pedindo por exemplo a Carlos V que, ignorando a aliança firmada entre o cunhado e Francisco I, o provesse dos territórios que havia perdido pela divida e obrigação que com ele tinham, fruto dos seus laços familiares, sendo a "traição" do duque de Saboia resultado das artimanhas do monarca francês dedicando a Carlos de Saboia e ao seu filho laços de obligacion y amor (MAZARIO COLETO, Maria del Carmen - Isabel de Portugal ..., cit., p. 523).

${ }^{118}$ A estes juntavam-se ainda dois de Carlos V, dos seus cunhados, Maria da Hungria e Fernando, assim como da mulher deste Ana da Hungria e dos filhos destes. Possuía ainda três retratos dos seus filhos Filipe, Maria e Joana. (REDONDO CANTERA, Maria José Formación y gusto de la coleccion de la Emperatriz Isabel de Portugal, in El arte en las Cortes de Carlos Vy Felipe II, Madrid: Consejo Superior de Investigacion Cientifica, 1999, p. 225-236, p. 232-233). 
mostrar a sua ilustre linhagem a quem a visitava ${ }^{119}$. A imagem de grandeza de uma família baseava-se assim nos símbolos e comportamentos dos seus membros, sendo este no fim o objectivo de D. Manuel ao escrever as suas Instruções para a sua filha Beatriz.

\section{6. desejo de serdes a maior acabada e prefeyta princesa que nunca foy $^{120}$ : Conclusão}

Esta seria a razão que terá levado D. Manuel a escrever as suas Instruções à sua filha D. Beatriz aquando do seu casamento em 1521, texto central e determinante na compreensão do que representava e era considerado o paradigma de consorte real em Portugal no século XVI. Quem melhor que um rei para sumarizar o que se esperava de uma consorte?

A visão das mulheres da família real como sombras que convivem com as fontes de poder no início da Idade Moderna, sem terem qualquer papel activo a não ser aquele que lhes corresponde como fruto da administração das suas casas (com tudo o que isso comporta) e o seu papel de perpetuadoras dinásticas, deve ser desconstruído. No âmbito das relações privadas da família e da casa, a mulher detinha um papel central e determinante, acima de tudo como a segunda pessoa que formava a unidade constituída pelos cônjuges, sendo que no caso da família real esta dinâmica assumia proporções diferentes da demais sociedade. Os próprios moralistas e pedagogos do início da Época Moderna, defendendo ou não a inferioridade da mulher face ao homem no campo social, político e intelectual ${ }^{121}$, apontavam o papel de apoio e conselheira do seu esposo, para as jovens que se casavam ${ }^{122}$.

${ }^{119} \mathrm{~A}$ estes devem-se acrescentar os objectos trazidos no enxoval destas princesas que utilizavam estes como reflexos das suas origens e mecanismos de memórias dinásticas. Cf. SÁ, Isabel dos Guimarães - Coisas de princesas: casamentos, dotes e enxovais na família real portuguesa (1480-1580)", in Revista de História da Sociedade e da Cultura. Vol. 10, 2010, T. 1, p. 97-120, p. 119).

${ }^{120}$ Cit. por CARVALHO, José Adriano de Freitas - Pais e Nobres..., cit., Vol. I, p. 265.

${ }^{121}$ BUESCU, Ana Isabel - Imagens do príncipe ..., cit., p. 215-216.

${ }^{122}$ Francisco de Monçon, por exemplo, coloca a capacidade de dar Sábios conselhos ao rei como a primeira das qualidades que uma rainha deve ter (BUESCU, Ana Isabel - Imagens do príncipe ..., cit., p. 217). 
Se é verdade que as crónicas silenciam na sua maior parte das vezes o papel das mulheres da família real, para além do seu desempenho caritativo e como mães, também é verdade que as mesmas obedecem muitas vezes a determinados programas e ideais políticos. O papel das mulheres na esfera familiar assentava no engrandecimento e perpetuação da sua casa, através das práticas defendidas para o seu género, não sendo os membros da família real excepção. Estas práticas passavam pelo conselho (não se podendo negar o poder da dialéctica entre cônjuges ${ }^{123}$ ), o governo da casa (real neste caso), devoção, virtude e beneficência (área de apanágio por excelência das rainhas), a criação de herdeiros e transmissores da dinastia, constituindo benefícios que a figura da esposa do rei transmitia à monarquia por direito e moto próprio, fruto do papel que a sociedade esperava do seu género e da sua condição ${ }^{124}$.

Estas eram as práticas esperadas das jovens que se casavam, tendo-as aprendido desde cedo e vindo a ensiná-las mais tarde às suas próprias filhas. A educação dava além disso uma grande importância aos comportamentos e consciência social principalmente no caso das jovens nobres e da família real. Nesta dinâmica de procura de engrandecimento da casa, a nobreza, investiria assim cada vez mais na educação e casamento das filhas ${ }^{125}$, não sendo a família real excepção.

A mãe servia de modelo de virtude e qualidades para a filha que agora se educava. Nesta mesma linha de acção pedagógica surgiam ainda as figuras femininas mais próximas, avós, tias, damas, ou, num registo mais afastado, aquelas ilustres mulheres, santas e rainhas, que pululam na literatura e cronística da época, servindo as suas vidas de exemplo e modelo ideológico na formação da jovem. O exemplo de Santa Ana a ensinar a Virgem Maria era neste período um tema recorrente na arte, simbolizando ao máximo o ideal de mãe que transmite os seus ensinamentos à filha que por sua vez servirá de mestre à sua própria prole ${ }^{126}$.

${ }^{123}$ EARENFIGHT, Theresa - Without the Persona of the Prince..., cit., p. 12.

${ }^{124}$ EARENFIGHT, Theresa - Without the Persona of the Prince..., cit., p. 9.

${ }^{125}$ CUNHA, Mafalda Soares da e MONTEIRO, Nuno Gonçalo - Aristocracia, Poder e Familia ..., cit., p. 51.

${ }^{126}$ HOWE, Elizabeth Teresa - Education and Women ..., cit., p. XIII. 
No caso português, ao contrário de muitas das suas congéneres europeias, as rainhas nunca foram alvo de rituais de sacralização ou formalização, como tal a sua "institucionalização" advinha como situação sine qua non do seu casamento e do título que adquiriam através de uma dinâmica resultante do ideal de que os nubentes tornavam-se uma unidade "carne de uma só carne " 127 . No entanto, esta falta de um acto formalizador não representa de todo que estas mulheres que desempenhavam um papel central na monarquia não fossem consideradas uma força política por si só.

Na mente de D. Manuel, ao escrever as suas Instruções, estariam talvez as palavras de Afonso X, segundo quem “Amar debe el rey á la reyna su muger por tres razones: la primera porque él et ella por casamiento segundo nuestra ley son como una cosa (...); la segunda porque ella solamente debe ser su compañia en los sabores et en los placeres, et otrosi ella ha de seer su parcera en los pesares et en los cuidados; la tercera porque el linage que de ella ha ó espera haber que finque en su lugar después de su muerte. Honrarla debe otrosi por tres razones: la primera porque pues ella es una cosa con el, quanto mas honrada fuere, tanto es él mas honrado por ella: la segunda, porque quanto mas la honrare, tanto habrá ella mayor razón de querer siempre su bien et su honra; la tercera porque seyendo ella honrada, serán los fijos que della hobiere mas honrados et mas nobles (...)." 128

${ }^{127}$ HESPANHA, António Manuel - Carne de uma só carne ..., cit., p. 952.

${ }^{128}$ ALFONSO X - Las Siete Partidas ..., cit., tm. II, Partida II, Titulo VI, Lei II, p. 48-49. 